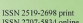

НАУКОВИЙ ВІСНИК

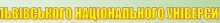

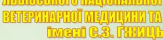

cientific messenger of Lviv National University

and

TIMU

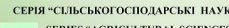

Том 23 № 94 2021
Науковий вісник Дьвівського національного університету ветеринарної медицини та біотехнологій імені С.3. Гжицыкого. Серія: Сільськогосподарські науки

\section{Scientific Messenger of Lviv National University of Veterinary Medicine and Biotechnologies. Series: Agricultural sciences}

https://nvlvet.com.ua/index.php/agriculture

UDC 57.05:612.063:636.12

\title{
Bioregulatory approach to stimulating sport horses
}

\author{
K. O. Skoryk ${ }^{1}$, S. V. Girin ${ }^{1}$, S. E. Kokish ${ }^{2}$, I. I. Tatsyuk ${ }^{1}$, O. V. Dobrovolskyi ${ }^{1}$ \\ ${ }^{1}$ Ukrainian Academy of Biological Medicine, Kiev, Ukraine \\ 2 "PF "Svitlana" - breeding reproducer of the Ukrainian horse breed, Boryspil district, Kiev region, Ukraine
}

\section{Article info}

Received 26.01.2021

Received in revised form 01.03 .2021

Accepted 02.03.2021

Ukrainian Academy of Biological Medicine, Vasilenka Str., 7, Kiev, 03124, Ukraine.

Tel: +38-095-414-45-98

E-mail: skoryk@cascade-

medical.com.ua

"PF "Svitlana"- breeding reproducer of the Ukrainian horse breed, Tsentralna Str., 69-A, Boryspil district, Kiev region, 08352, Ukraine.
Skoryk, K. O., Girin, S. V., Kokish, S. E., Tatsyuk, I. I., \& Dobrovolskyi, O. V. (2021). Bioregulatory approach to stimulating sport horses. Scientific Messenger of Lviv National University of Veterinary Medicine and Biotechnologies. Series: Agricultural sciences, 23(94), 31-35. doi: $10.32718 /$ nvlvet-a9406

The presented work presents the results of the effectiveness of the bioregulatory approach in stimulating sports horses. The aim of the study was to find a way to safely restore the energy balance and prevent the occurrence of inflammatory processes in the musculoskeletal system during significant physical exertion. Sport horses spend a lot of energy not only in competition, but also during daily training. Such loads require a high supply of energy. Often the body uses its last reserves to compensate for its energy needs, which leads to exhaustion and the appearance of various diseases. First of all, diseases occur in the musculoskeletal system, because it is the limbs that bear the greatest load during training. As you know, various synthetic doping is introduced to keep animals in a sporty tone. Their action is not long-lasting, but it has many side effects for the animal's body and leads to disruption of the functioning of organs and systems. Today, there is an alternative to such stimulation methods thanks to a bioregulatory approach in the treatment of animals using preparations containing exclusively natural ingredients. To confirm the effectiveness of the use of bioregulatory drugs, clinical and laboratory studies of animal blood (general, biochemical, cytochemical) were carried out. The main changes in laboratory parameters were obtained by cytochemical analysis of such enzymes as GPDH, SDH. These enzymes are among the main indicators of the intensity of energy metabolism in the horse's body. The quantitative composition of basophils and eosinophils has also changed, which indicates a decrease in the level of the inflammatory process in the body of experimental animals. The results obtained prove the effectiveness of the investigated drugs and their direct influence on the energy balance of the "horse-athlete". Thanks to the natural composition of the components of the preparations used, side effects on the body can be avoided and used without restrictions throughout the horse's sports career.

Key words: racehorses, Ukrainian riding breed, training, bioregulation medicine, Heel Vet, Traumeel, Coenzyme compositum, energy metabolism, inflammatory process, hematological parameters.

\section{Біорегуляційний підхід в стимуляції спортивних коней}

\author{
К. О. Скорик ${ }^{1}$, С. В. Гірін ${ }^{1}$, С. Є. Кокіш ${ }^{2}$, I. І. Тацюк ${ }^{1}$ О. В. Добровольський
}

${ }^{l}$ Украӥнська Академія Біологічної медицини, м. Київ, Украӥна

${ }^{2}$ СФГ “Світлана” - племінний репродуктор украӥнської верхової породи коней, Бориспільський район, Київська область, Украӥна

У даній роботі викладені результати ефективності біорегулячійного підходу в стимулячії спортивних коней. Метою дослідження був пошук иляху безпечного відновлення енергетичного балансу та запобігання виникненню запальних процесів в опорно-руховому апараті при значних фізичних навантаженнях. Спортивні коні затрачають багато енергї не тільки на змаганнях, а й під час щзоденних тренінгів. Такі навантаження вимагають високого забезпечення енергією. Часто організм, аби компенсувати свої енергетичні потреби, використовує останні резерви, щзо веде до виснаження та появи різних захворювань. Насамперед захворювання виникають в опорно-руховому апараті, адже саме на кінцівки припадає найбільше навантаження під час тренувань. Для 
підтримання тварин в спортивному тонусі вводять різні синтетичні допінги. Їхня дія нетривала, проте має багато побічних наслідків для організму коня та призводить до порушення роботи органів і систем. Нині є альтернатива таким методам стимуляиї завдяки біорегуляиійному підходу у лікуванні тварин з використанням препаратів, шо містять виключно натуральні компоненти. Для підтвердження ефективності застосування біорегуляційних препаратів були проведені клінічні та лабораторні дослідження крові тварин (загальні, біохімічні, ичтохімічні). Головні зміни в показниках були отримані при ичттохімічному аналізі таких ферментів, як ГФДГ, СДГ. Ці ензими є одними з основних показників інтенсивності енергетичного обміну в організмі коней. Також змінився кількісний склад базофілів та еозинофілів, щзо свідчить про зниження рівня запального процесу в організмі піддослідних тварин. Отримані результати доводять ефективність досліджуваних препаратів та їхній прямий вплив на енергетичний баланс “коня-спортсмена”. Завдяки натуральному складу компонентів застосовуваних препаратів можна уникнути побічного впливу на організм та без обмежень використовувати протягом всієї спортивної кар'єри коня.

Ключові слова: скакові коні, украӥнська верхова порода, тренінг, біорегуляційна медицина, Нееl Vеt, Tраумель, Коензим композитум, енергетичний обмін, запальний процес, гематологічні показники.

\section{Вступ}

Кінний спорт в нашій країні є досить популярним як серед професіоналів, так і просто любителів коней. Спортивні породи коней вимагають особливого підходу до утримання, включаючи збалансоване харчування і обов'язкові тренінги. У зв'язку 3 постійним збільшенням вимог до жвавості чистокровних порід коней, зростає потреба у великій кількості енергії, яку часто намагаються компенсувати за допомогою синтетичних препаратів-стимуляторів енергетичного обміну (Brejtsher et al., 1971; Allen et al., 1979; Kaljuzhnyj, 1983; Snow et al., 1983).

Насамперед скакового коня потрібно розглядати як спортсмена, для якого шлях до перемоги на змаганнях лежить через тренінги (Laskov, 1973; Kollom, 1984). Завдяки їм організм стає витривалішим через адаптації його до фізичних навантажень. Під адаптацією розуміють ряд змін, характерних для тварин спортивних порід, пов'язаних 3 функціонуванням органів і систем, 3 активною роботою опорнорухового апарату, збільшенням споживання кисню, прискоренням метаболізму, набуття нових навичок та якостей і т. д. Внаслідок тренінгу організм коня адаптується в умовах значних фізичних навантажень для забезпечення фізіологічного існування (Kul'chickaja \& Pimenova, 1982; Laskov et al., 1988).

Головним правилом в тренінгу коней $є$ його систематичність. Перерви в тренуваннях спортивних коней можуть призвести не тільки до втрати набутих навичок, а й до згасання функціональних можливостей переважно серцево-судинної і дихальної систем, а також до незворотних змін, наприклад таких, як атрофія м'язів. Систематичні тренінги не тільки підтримують рівень тренованості коней, а й підвищують шанси на перемогу в змаганнях (Laskov et al., 1982; Volynskij, 2004).

Відомо що, будь-які фізичні тренування вимагають значних затрат енергії, тому важливу роль у цьому процесі відіграє енергетичне забезпечення м'язів. Утворення енергії відбувається внаслідок хімічних реакцій гліколізу і окисного фосфорилювання. Реакція гліколізу протікає без участі кисню. Окислювальне фосфорилювання, як і часткове окислення молочної кислоти (лактату), вимагає кисневої присутності (Laskov et al., 1972; Alekseev, 1977; Karpman, 1994).

Всі хімічні реакції енергетичних процесів проходять в спеціальних клітинних органелах - в мітохондріях. Ця структурна одиниця енергетичного обміну продукує енергію у вигляді аденозинтрифосфорної кислоти (АТФ). Запаси АТФ в організмі коня обмежені, тому для виконання значної м'язової роботи необхідний безперервний потік енергії (Bobylev, 1961; Alekseev, 1977).

Відновлення молекули АТФ може протікати шляхом дихального і гліколітичного фосфорилювання. Гліколітичне фосфорилювання - це безкисневий шлях ресинтезу АТФ. Оскільки скакові коні мають значні запаси вуглеводів, то відповідно гліколіз може досить тривалий час відновлювати АТФ. Кінцевим продуктом анаеробного розпаду є лактат (молочна кислота). При інтенсивному фізичному навантаженні у скакових коней спостерігається збільшення кількості лактату в крові та частішає дихання (зростає потреба в кисні) (Meshkova, 1979; Nehvjadovich, 2000). Надлишки спожитого кисню (кисневий борг) в період відновлення витрачаються на окислення деякої кількості лактату в тканинах печінки і серця. Та частина лактату, яка накопичується в крові при швидкому бігу коня, перетворюється в печінці назад в глікоген.

Всі вищеперераховані процеси відбуваються фізіологічно, але при тривалих та інтенсивних тренуваннях організм коня, аби компенсувати потребу в енергії, починає використовувати резервні запаси організму, що призводить до його виснаження (Gurevich, 2001). Внаслідок цього порушується біологічна рівновага, знижується імунітет тварини, відбуваються метаболічні та морфологічні зміни в тканинах, підвищується схильність до розвитку захворювань, особливо опорно-рухового апарату, оскільки саме на нього спрямоване все фізичне навантаження під час тренінгу (Seehermann \& Morris, 1989).

У плані фармакологічної корекції енергетичного обміну і запобігання розвитку запалення в суглобах $\mathrm{i}$ м'язах спортивних коней заслуговують на увагу препарати, які в своєму складі мають натуральні компоненти. Ці препарати володіють такими властивостями: мають високий профіль безпеки і можливість застосування для профілактики на постійній основі. Саме такими якостями володіють біорегуляційні препарати TM Heel Траумель і Коензим композитум. Біорегуляційна медицина являє собою інноваційний підхід в лікуванні організму, який розглядає захворювання комплексно, підтримує ідею ауторегуляції 3 орієнтуванням на усунення тих порушень регуляції в біологічних мережах, які лежать в основі захворювань. Завдяки біологічному підходу до організму тварини можна повністю компенсувати енергетичні витрати організму після фізичних навантажень, запобіг- 
ти появі захворювань на ранніх стадіях, а також безпечно стимулювати організм “спортсмена".

В даному дослідженні була доведена ефективність препаратів Траумель і Коензим композитом на скакових конях. Два препарати використовувалися в комплексі, взаємодоповнюючи і підсилюючи дію кожного.

У складі препарату Траумель - 15 натуральних компонентів мінерального і рослинного походження. Він діє протизапально, антиексудативно, регенеруюче. Препарат Траумель здатний швидко усунути набряк і невеликі крововиливи в місці пошкодження м'яких тканин, знеболити, підвищити тонус кровоносних судин, знизити їх проникність і сприяти зупинці кровотеч. Також перераховані вище властивості препарату Траумель дозволяють мінімізувати можливі ускладнення (усувати венозний застій, протидіяти утворенню тромбів) і в найкоротші терміни провести реабілітацію ушкоджень, що особливо важливо в спортивній ветеринарній медицині. Препарат $є$ універсальним протизапальним засобом і був призначений в даному дослідженні з метою профілактики розвитку запального процесу переважно в опорноруховому апараті спортивних коней.

Другим досліджуваним препаратом був Коензим композитум, який показаний при стимуляції і регуляції діяльності внутрішньоклітинних ферментних систем, в основному на рівні циклу лимонної кислоти при хронічних захворюваннях опорно-рухового апарату, органів дихання, серцево-судинної системи, церебро-васкулярної патології, сечостатевої системи, шлунково-кишкового тракту та ін.; гіповітамінозах і фізичному виснаженні. Коензим композитум здатний активізувати процес окисного фосфорилювання.

Мета дослідження - обгрунтувати можливість ефективного комплексного використання препарату Траумель і Коензим композитум для повного відновлення організму коней після значного фізичного навантаження.

\section{Матеріал і методи досліджень}

Дослідження проводилось на 12 головах клінічно здорових скакових коней української верхової породи на базі племрепродуктора ФСГ “Світлана” Бориспільського р-ну Київської області.

Українська верхова порода $є$ спортивною породою, призначеною для класичних видів кінного спорту.

Всі тварини, які брали участь в дослідженні, були жеребцями або меринами. Середній вік тварин 6 років, середня вага - 470 кг. Утримання безприв'язне в стійлі розміром 4 м на 5 м. Годування - 3-разове. В раціоні - ячмінь, овес, висівки і сіно. Всі коні скакові.

Режим тренування досліджуваних коней становив 6 разів на тиждень. Спільна робота на корду -45 хвилин. Стрибки -2 рази в тиждень (таблиця 1).

\section{Таблиця 1}

Режим тренінгу коней СФГ “Світлана”

\begin{tabular}{lc}
\hline \multicolumn{1}{c}{ Вид тренування } & Тривалість тренування в \\
& хвилинах \\
\hline Риссю & 15 \\
Кроком & 15 \\
Галопом & 15 \\
\hline
\end{tabular}

Згідно з протоколом дослідження тварини були розділені на 2 групи. Першій піддослідній групі $(\mathrm{n}=6)$ під час тренінгів вводили в/м препарати Траумель і Коензим композитум по 10 мл кожного з інтервалом 1 раз на 3 дні загальним курсом 7 ін'єкцій. Другій групі $(\mathrm{n}=6)$ - фізіологічний розчин за аналогічною схемою.

Результати дослідження оцінювали за лабораторними даними аналізу крові. Під час всього дослідження проводили клінічний огляд тварин. Кров відбирали в обох групах з яремної вени двічі - до і після закінчення дослідження. Загальний аналіз крові проводили на аналізаторі ABX Pentra $60 \mathrm{C}+$, біохімічний аналіз на приладі Microlab 300. При проведенні цитохімічного аналізу визначали такі ферменти: НАД, СДГ і ГФДГ. У дослідженні визначали активність ензимів азотистого обміну аланінамінотрансферази (СС 2.6.1.2) (ALT), аспартатамінотрансфераза (ЕC 2.6.1.1) (AST) в лімфоцитах.

Також були розраховані показники енергетичного обміну коней до і після впливу препарату Траумель і Коензим композитум. Для оцінки статистично значущих змін експериментальної вибірки порівняно 3 контролем використовували непараметричний критерій знаків G. Для оцінки характеру і сили взаємозв'язку між контрольною та експериментальною групами використовували парний кореляційний r-індекс. Для всього аналізу статистична значущість була встановлена на рівні $\mathrm{P}<0,05$ (Tietz, 1995).

\section{Результати та їх обговорення}

Інтенсивні навантаження вимагають значних затрат енергії, що призводить до характерних змін в картині крові, а також симптоматично може проявлятись у вигляді захворювань опорно-рухового апарату. В результаті клінічного обстеження в піддослідній групі ніяких змін, крім підвищення жвавості, не спостерігалось. При клінічному огляді контрольної групи у коней на прізвисько Букет, Санні-Монако і Бріг спостерігалася легка кульгавість після інтенсивної роботи ( стрибки), а також загальне пригнічення.

За допомогою критерію знаків $\mathrm{G}$ для вибірки $\mathrm{n}=6$ були виявлені достовірні зміни гематологічних показників в піддослідній групі, якій вводили препарати Траумель і Коензим композитум.

В отриманих результатах аналізів крові були виявлені зміни в таких показниках: АЛТ Од/л, еозинофіли \%, базофіли \%, Лактат, ГФДГ і СДГ. Решта показників в піддослідній групі, а також в контрольній групі були без змін (табл. 2). 
Таблиця 2

Результати аналізу крові піддослідних коней

\begin{tabular}{|c|c|c|c|c|c|c|c|c|c|c|}
\hline \multirow{3}{*}{$\begin{array}{l}\text { № } \\
\Pi / \Pi\end{array}$} & \multirow{3}{*}{ Кличка } & \multirow{3}{*}{ Стать } & \multirow{3}{*}{$\begin{array}{c}\text { Вага, } \\
\text { кг }\end{array}$} & \multirow{3}{*}{$\begin{array}{c}\text { Дата } \\
\text { наро- } \\
\text { дження }\end{array}$} & \multicolumn{6}{|c|}{ Показники } \\
\hline & & & & & \multicolumn{2}{|c|}{ АЛТ, Од/л } & \multicolumn{2}{|c|}{ Еозинофіли, \% } & \multicolumn{2}{|c|}{ Базофіли, \% } \\
\hline & & & & & $\begin{array}{c}\text { початок } \\
\text { досліду }\end{array}$ & $\begin{array}{c}\text { кінець } \\
\text { досліду }\end{array}$ & $\begin{array}{c}\text { початок } \\
\text { досліду }\end{array}$ & $\begin{array}{c}\text { кінець } \\
\text { досліду }\end{array}$ & $\begin{array}{l}\text { початок } \\
\text { досліду }\end{array}$ & $\begin{array}{l}\text { кінець } \\
\text { досліду }\end{array}$ \\
\hline 1 & Габріель & Жеребець & 480 & 2016 & 12,4 & 10,65 & 4,8 & 4,3 & 0,4 & 0,2 \\
\hline 2 & Вашингтон & Жеребець & 500 & 2015 & 10,1 & 9,78 & 3,9 & 2,2 & 0,5 & 0,3 \\
\hline 3 & Енгергальд & Жеребець & 550 & 2013 & 10,48 & 9,25 & 3,3 & 2,5 & 0,3 & 0,2 \\
\hline 4 & Бурштин & Мерин & 570 & 2015 & 11,87 & 11,87 & 2,5 & 2,8 & 0,2 & 0,1 \\
\hline 5 & Opic & Жеребець & 480 & 2012 & 13,8 & 11,52 & 3,7 & 3,4 & 0,6 & 0,4 \\
\hline \multirow[t]{2}{*}{6} & Бельмондо & Мерин & 400 & 2018 & 17,1 & 14,67 & 7,2 & 5,5 & 0,5 & 0,3 \\
\hline & $\mathrm{M} \pm \mathrm{m}$ & & & & $12,62 \pm 1,8$ & $11,29 \pm 1,4$ & $4,23 \pm 1,17$ & $3,45 \pm 0,96$ & $0,42 \pm 0,11$ & $0,25 \pm 0,08$ \\
\hline
\end{tabular}

\begin{tabular}{|c|c|c|c|c|c|c|c|c|c|c|}
\hline \multirow{3}{*}{$\begin{array}{c}\text { № } \\
\Pi / \Pi\end{array}$} & \multirow{3}{*}{ Кличка } & \multirow{3}{*}{ Стать } & \multirow{3}{*}{$\begin{array}{c}\text { Вага, } \\
\text { кг }\end{array}$} & \multirow{3}{*}{$\begin{array}{c}\text { Дата } \\
\text { наро- } \\
\text { дження }\end{array}$} & \multicolumn{6}{|c|}{ Показники } \\
\hline & & & & & \multicolumn{2}{|c|}{ Лактат, ммоль/л } & \multicolumn{2}{|c|}{ ГФДГ, Од/л } & \multicolumn{2}{|c|}{ СДГ, Од/л } \\
\hline & & & & & початок & кінець & початок & кінець & початок & кінець \\
\hline 1 & Габріель & Жеребець & 480 & 2016 & 2,43 & 1,79 & 1,33 & 3,01 & 5,72 & 9,66 \\
\hline 2 & Вашингтон & Жеребець & 500 & 2015 & 1,89 & 1,79 & 0,6 & 3,01 & 6,21 & 9,66 \\
\hline 3 & Енгергальд & Жеребець & 550 & 2013 & 2,71 & 1,73 & 0,65 & 4,26 & 6,49 & 6,53 \\
\hline 4 & Бурштин & Мерин & 570 & 2015 & 2,13 & 1,70 & 0,89 & 1,58 & 5,7 & 6,85 \\
\hline 5 & Opic & Жеребець & 480 & 2012 & 2,23 & 2,10 & 1,13 & 1,45 & 5,41 & 8,9 \\
\hline \multirow[t]{2}{*}{6} & Бельмондо & Мерин & 400 & 2018 & 3 & 2,13 & 0,51 & 3,1 & 6,5 & 8,25 \\
\hline & $\mathrm{M} \pm \mathrm{m}$ & & & & $2,39 \pm 0,31$ & $1,87 \pm 0,16$ & $0,85 \pm 0,26$ & $2,73 \pm 0,81$ & $6,0 \pm 0,39$ & $8,30 \pm 1,09$ \\
\hline
\end{tabular}

Еозинофіли і базофіли являють собою формені елементи крові і виконують захисну функцію в організмі тварин. Достовірне зниження їхнього рівня (згідно 3 критерієм знаків G) в отриманих результатах свідчить про зниження запального процесу в організмі, що періодично виникає в період інтенсивної роботи. Зупинка запального процесу на ранньому етапі свого розвитку дає можливість профілактувати виникнення ускладнень у вигляді кульгавості, тендинітів, міозитів і т.д.

Ензими ГФДГ (гліцерофосфатдегідрогеназа), СДГ (сукцинатдегідрогеназа) та НАД (нікотинамідаденіндинуклеотидфосфа́т) беруть участь в енергетичному процесі. Ці ферменти є невід'ємними компонентами циклу Кребса і другого комплексу дихального ланцюга мітохондрій. Достовірне збільшення таких ферментів, як ГФДГ і СДГ в крові коней дослідної групи, дає підставу говорити про поліпшення споживання клітин м'язової тканини киснем за рахунок активізації внутрішньоклітинного енергетичного обміну.

Лактат, або молочна кислота, є кінцевим продуктом гліколізу, що утворюється при тренуваннях. АЛТ (аспартатамінотрансфераза) являє собою ендогенний фермент, який бере участь в перерозподілі енергетичних субстратів. Зміна рівня лактату і АЛТ відображає специфічні перетворення в структурі метаболізму робочих коней спортивного напрямку. В даному дослідженні зниження лактату і АЛТ свідчить про підвищення внутрішньом'язових резервів енергетичних речовин та зниження рівня закислення внутрішньом'язового середовища i, як наслідок, клінічно проявляється підвищенням працездатності організму коня.

\section{Висновки}

Отримані результати аналізу крові дослідної групи коней свідчать про активізацію енергетичного обміну на клітинному рівні.

При проведені клінічного обстеження піддослідних тварин (яким вводили препарати Траумель і Коензиму композитум) була виявлена лише підвищена жвавість у поведінці. Інших патологічних ознак при огляді коней не спостерігали (наприклад - кульгавості, набряків, вивихів і т. д.).

Отримані результати дають можливість говорити про високу ефективність застосування препаратів Траумель і Коензим композитум для спортивних коней 3 метою підвищення їхньої працездатності, активізації енергетичного обміну, зниження існуючого запального процесу в опорно-руховому апараті робочих коней, а також його профілактику в період інтенсивної роботи або перед змаганнями.

Препарати Траумель і Коензим композитум можна рекомендувати для застосування коням в період інтенсивних тренувань, а також перед змаганнями або в комплексних схемах лікування різних захворювань, що вимагають протизапального i стимулюючого ефекту.

Перспективи подальших досліджень. Проблема правильної стимуляції спортивних коней є відкритою на сьогодні та потребує додаткового пошуку перевірки безпечності й ефективності нових фармакологічних засобів. Перевагу варто надавати сучасним біорегуляційним препаратам завдяки їх безпечності та комплексній дії на тваринний організм. Обрані методи стимуляції мають не лише підтримувати необхідний енергетичний рівень коня, а й володіти протизапальним ефектом 3 прямим впливом на опорно-руховий апарат. Згідно 3 
результатами проведеної роботи, дія застосованих препаратів Траумель та Коензим композитум була підтверджена лабораторними дослідженнями, що свідчить про ефективність даного способу стимуляції та перспективність проведення подальших експериментів в цьому напрямку.

\section{References}

Alekseev, M. Ju. (1977). Biohimicheskij kontrol' treninga Konevodstvo i konnyj sport, 7, 29-30 (in Russian).

Allen, B. V., \& Archer, R. K. (1979). Some haematological values in English thoroughbred horses. Vet. Ree., 98(10), 195-196. doi: 10.1136/vr.98.10.195.

Bobylev, I. F. (1961). Sdvigi v klinicheskih i gematologicheskih pokazateljah u sportivnyh loshadej v processe sorevnovanij. Sb. nauch. tr. MVA, 35, 98101 (in Russian).

Brejtsher, I. L., Leonova, M. A., \& Ashibokov, L. H. (1971). Funkcional'noe sostojanie dvigatel'nogo analizatora loshadi. Sb. nauch. tr. VNII konevodstva, 104-107 (in Russian).

Gurevich, D. Ja. (2001). Spravochnik po konnomu sportu i konevodstvu. Moskva. Centrpoligraf, 240-258 (in Russian).

Kaljuzhnyj, A. (1983). Bor'ba s tendinitami. Konevodstvo i konnyj sport, 2, 30-31 (in Russian).

Karpman, V. L. (1994). Serdechno-sosudistaja sistema i transport kisloroda pri myshechnoj rabote. Klinikofiziologicheskie harakteristiki serdechno-sosudistoj sistemy u sportsmenov: sb. nauch. rabot kaf. sport, med. RGAFK. Moskva, 12-41 (in Russian).

Kollom, R. (1984). Federiko Grizone (Grizo). Konevodstvo i konnyj sport, 4, 28 (in Russian).

Kollom, R. (1984). Pljuvinel'. Konevodstvo i konnyj sport, 5, 31 (in Russian).

Kul'chickaja, G. R., \& Pimenova, T. I. (1982). Biologicheskie osobennosti i rabotosposobnost' sportivnyh loshadej. Sb. nauch. tr. MVA, 26, 93-96 (in Russian).
Laskov, A. A. (1973). Dinamika fiziologicheskih funkcij i rabotosposobnosti loshadej pod vlijaniem gipoksii: avtoref. dis.d-ra biol. nauk: 03.00.13 Rostov-na-Donu (in Russian).

Laskov, A. A. (2000). Konnyj sport. Prakticheskoe konevodstvo. Moskva, 166-176 (in Russian).

Laskov, A. A., Leonova, M. A., \& Parysheva, L. P (1972). Adaptacija loshadej k hronicheskoj i ostroj gipoksii Moskva: Rossel'hozizdat, 24-67 (in Russian).

Laskov, A. A., Sergienko, S. S., \& Sergienko, G. F. (1988). Sredstva uskorenija vosstanovlenija funkcional'nogo sostojanija sportivnyh loshadej posle intensivnyh fizicheskih nagruzok: Metodicheskie rekomendacii. VNIIK. Moskva, 8-23 (in Russian).

Laskov, A. A., Sergienko, S. S., \& Sergienko, G. F. (1982). Trening i ispytanija skakovyh loshadej. Moskva, 4-12 (in Russian).

Meshkova, N. P. (1979). Biohimija myshc. Moskva. Izdvo Moskovskogo un-ta, 92-110 (in Russian).

Nehvjadovich, A. I. (2000). Gematologicheskij kontrol' v sporte. Mn. RUMC, 11-42 (in Russian).

Seehermann, H. J., \& Morris, E. A. (1989). Equisport: a clinical equine sports medicine program. Equine vet. Sc., 9(4), 193-197. URL: https://agris.fao.org/agrissearch/search.do?recordID $=$ US9050876.

Snow, D. H., Ricketts, S. W., Mason, D. K. (1983). Haematological response to racing and training exercise in Thoroughbred horses, with particular reference to the leucocyte response. Equine Vet J., 15(2), 149-154. doi: 10.1111/j.2042-3306.1983.tb01742.x.

Tietz, N. W. (1995) Clinical Guide to Laboratory Tests (ELISA). 3rd Edition, W.B. Saunders, Co., Philadelphia, 22-23. URL: https://www.scirp.org/ (S(oyulxb452alnt1aej1nfow45))/reference/References Papers.aspx?ReferenceID=1641367.

Volynskij, S. M. (2004). Trenirovka i vyezdka loshadej. OOO "ACT"; Doneck: "Stalker". 116-210 (in Russian). 